\title{
Congress warns NASA not to raid science funds
}

[WASHINGTON] The US Congress told the National Aeronautics and Space Administration (NASA) last week that it must solve its cost problems in building the international space station without raiding funds allocated to science programmes.

House of Representatives and Senate appropriations committees granted the agency $\$ 148$ million beyond its $\$ 13.5$ billion request for the 1998 fiscal year, which began last week. But they specifically denied a request from NASA to transfer money from the science, aeronautics and technology account to help pay for a projected shortfall of $\$ 430$ million in 1998 for space station construction.

While sending a strong signal that Congress will not allow the station to cannibalize the agency's Earth and space science programmes, the move puts NASA in a difficult position. Even with an extra $\$ 100$ million for the station, and permission to move $\$ 130$ million in "mission support" (largely salaries and administrative costs) and other funds, the agency remains $\$ 200$ million short of what it says it needs in the coming year to keep the station on track.

The agency's administrator, Daniel Goldin, warned a Senate committee last month that without $\$ 430$ million in new funding and transfer authority, work on the station could slip. This in turn could delay its 2003 completion date and increase its total cost of $\$ 17$ billion.

NASA and its main contractor for the station, Boeing, estimate the station will be $\$ 600$ million over budget by the time it is finished. Only $\$ 100$ million of the 1998 shortfall is caused by problems in accommodating Russian hardware delays, the rest being attributed to schedule overruns and development problems at Boeing.

Congress has become increasingly alarmed at growing projections for the shortfall, and is therefore imposing strict conditions on NASA's 1998 appropriation. The agency will receive only about twothirds of the $\$ 2.35$ billion allocated to the station until it produces (by 31 March) accounts showing exactly how much the project will cost to complete.

NASA will be asked to cooperate in this exercise with the congressional General Accounting Office (GAO), which has warned repeatedly of cost and schedule problems with the station, and has consistently estimated a higher final cost than NASA has.

Last week's decision showed once again the influence of Barbara Mikulski, the top Democrat on the Senate appropriations subcommittee that oversees NASA. Mikulski supports the station, but is even more concerned that it should not jeopardize funding for the Mission to Planet Earth and space science programmes that make up the majority of work conducted at the Goddard Space Flight Center in her home state of Maryland.

The station funding crisis adds to growing confusion at the space agency about its budget. In August the White House Office of Management and Budget (OMB) surprised NASA managers by telling them to request only $\$ 12.6$ billion from Congress in 1999 . That is a sharp reduction from the $\$ 13.4$ billion that NASA budget planners had been expecting, based on a five-year projection accompanying the administration's 1998 request.

Although NASA - and other federal agencies that also received low 1999 targets from $\mathrm{OMB}$ - have been told that their final request is likely to be higher, programme managers are left uncertain how much money they have to work with in the coming years.

If NASA had to live with a $\$ 12.6$ billion budget for 1999, says one agency official, it would be "disaster" and is likely to lead to cancellation of several high-priority proposed science initiatives. These include a robotic landing on Mars in 2001, a Mars sample return mission in 2005, a spacebased interferometry mission, the LightSAR imaging radar for Earth observation, and proposed increases for basic research and technology development. Tony Reichhardt

\section{UK's greenhouse reduction target 'hard but feasible'}

[LONDON] The British government's chief scientist, Sir Robert May, has acknowledged that the government's promise to reduce greenhouse gas emissions by 20 per cent of 1990 levels by 2010 will be "difficult" to achieve, but says it should remain a target.

Speaking at the launch of a briefing document on climate change written for Prime Minister Tony Blair, May said that reductions would have to come from all sectors of energy use: road transport, domestic use and industry. "Industry should see climate change as opportunity not as threat," he said.

But it appears unlikely that the government will formally commit itself to a 20 per cent reduction if - as is expected - the December conference of the United Nations climate convention in Kyoto, Japan, agrees on lower greenhouse gas targets. The UK government has said it will not outline specific policies and measures until well after the Kyoto conference.

An interdepartmental working group of officials from the departments of the environment and trade, and the Treasury, has begun to look into how Britain could achieve a 20 per cent reduction. An environment department spokesman says that the group is not expected to report until the middle of 1998 at the earliest. Meanwhile, the combined Department of the Environment, Transport and the Regions has begun drawing up proposals for an integrated transport policy.

EhsanMasood

\section{Surveyor maps desert valleys of Mars}

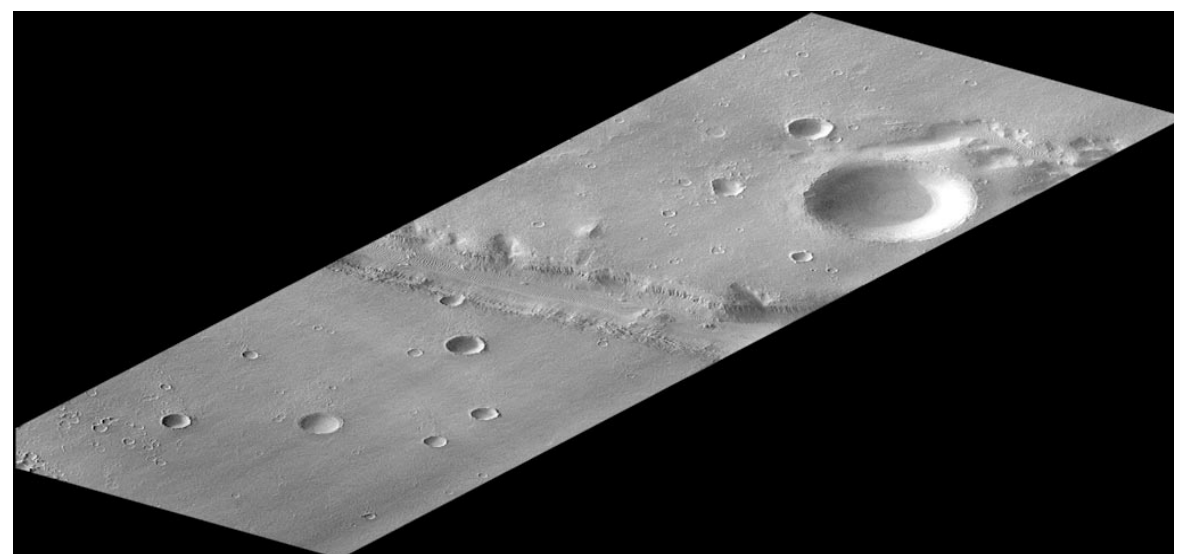

[LONDON] Preliminary images sent back by the orbiting Mars Global Surveyor show a desert-like terrain pock-marked with craters. The mapped region (above) is called Nirgal Vallis, which is one of a number of canyons known as valley networks.

The origin of these valleys is the subject of debate. Some believe they were formed by water flowing across the surface, but other suggest they were formed by the collapse and erosion associated with groundwater processes.

A closer look at the terrain is likely to help resolve the controversy. 